\title{
Communications Strategy PT. Taspen Branch Mataram for Implementation of Public Service
}

\author{
Yulanda Trisula Sidarta Yohanes ${ }^{1}$ \\ ${ }^{1}$ Communications Science of Mataram University \\ Corresponding Author's Email: landak.landa@gmail.com
}

\begin{abstract}
PT. Taspen is BUMN company engaged old age savings insurance for the state civil apparatus. Products owned by PT. Taspen not oly old age insurance, Taspen also introduce new product, namely Taspen Scholarship and Taspen Dwiguna Sejahtera. This study aims to assess the communication strategy practiced by employees for implementation of public services on the company's new products. The method used in this research is focus group discussion, observation, and documentation, as well as post test involving all employees of PT. Taspen to practice communication in introducing new products. This method shows outsiders as a medium of communication participant presentation to be able to demonstrate the communication skills of participants in dealing with various client characters. Based on the results of research using FGD, observation, documentation, post-test, strategic communication conducted by employees of PT. Taspen in relations with clients to do public speaking activities through several shelves, such as making personal contact by conducting personal communication before starting to introduce product, representing each group, showing readiness in explaining material, seeking complaints about the product Expected by representatives each group, the flexibility of communication participants by answering questions from the target, as well as the results of post tests about the marketing communication strategies carried out by the employees. Post-test results show about the increase of knowledge for marketing communication strategy by 27 employees.
\end{abstract}

Keywords: communications strategy, public speaking, public service

\section{INTRODUCTION}

PT. Taspen is BUMN company engaged old age savings insurance for the state civil apparatus. Products owned by PT. Taspen is not only an old-age savings program, pension program, death insurance program, and work accident insurance program, but also a new product namely Taspen Scholarship Protection and Taspen Dwiguna Sejahtera, and Taspen Save.

Taspen Scholarship Protection is an educational funding program for children. Taspen Dwiguna Sejahtera is a guaranteed life insurance protection program. And Taspen Save product is an insurance program to prepare for 
retirement. The three products that are owned by PT. Taspen is a new product that has the benefits of each.

The product knowledge must be possessed by the marketing team at PT. Taspen Branch Mataram. This product knowledge aims to convey information to prospective new customers to choose products that suit customer needs. In this research, product knowledge is not only owned by the marketing team, but also all employees of PT. Taspen Branch Mataram from leaders to subordinates. Problems faced by employees of PT. Taspen Branch Mataram is that not all employees have product knowledge. This is a big challenge for PT. Taspen, because a large competitor from PT Taspen Branch Mataram is BPJS Employment. Therefore, according to Mr. Sandy Pramuditha as the marketing division of PT. Taspen Branch Mataram said that "The position of PT. Taspen Branch Mataram is now ranked 17th in Indonesia after being led by the new branch head. He wants all his employees to know all the products in PT. Taspen Branch Mataram."

Based on the results of the pre-research interview above, explaining that PT. Taspen Branch Mataram tries to provide a breakthrough that the company is trying to provide the best service to prospective customers by involving all employees to be able to communicate about new products. Everyone is able to communicate, but the employees of PT. Taspen Branch Mataram are need a marketing communications strategy to provide service excellent

. The ability of public speaking employees of PT. Taspen Branch Mataram is a form of application in interacting with prospective corporate customers. The purpose of this research is explain the practice of strategy communications in PT. Taspen Branch Mataram for implementation of public service in dealing with types of customer's character. Many kind of character of customer require communication strategies in explaining new products to them, so that the ability of speak in public is needed to support the appearance of employees of PT. Taspen Branch Mataram in providing excellent service.

\section{LITERATURE REVIEW}

\section{Strategy of Communications}

the planning is the first step in making communications strategy. it is designed to identify the actions that will do by the company. the planning could be preparing employees for communicating with customers. Strategy of communications means the strategy is designed to change human behavior on a large scale through the transfer of new idea (Roger on Cangara, 2013: 64). There is one model communication that could be explain about change human behavior. It called S-O-R's Model (Stumulus, Organism, Response), that could be describe the model that explain how the phisycal environment influences individual in situations and behavior (Park, 2008 in article Listyandari with title "Aplikasi Model Stimulus Organism Response dalam Keputusan Pembelian Online). This model can be seen in the scheme below: 


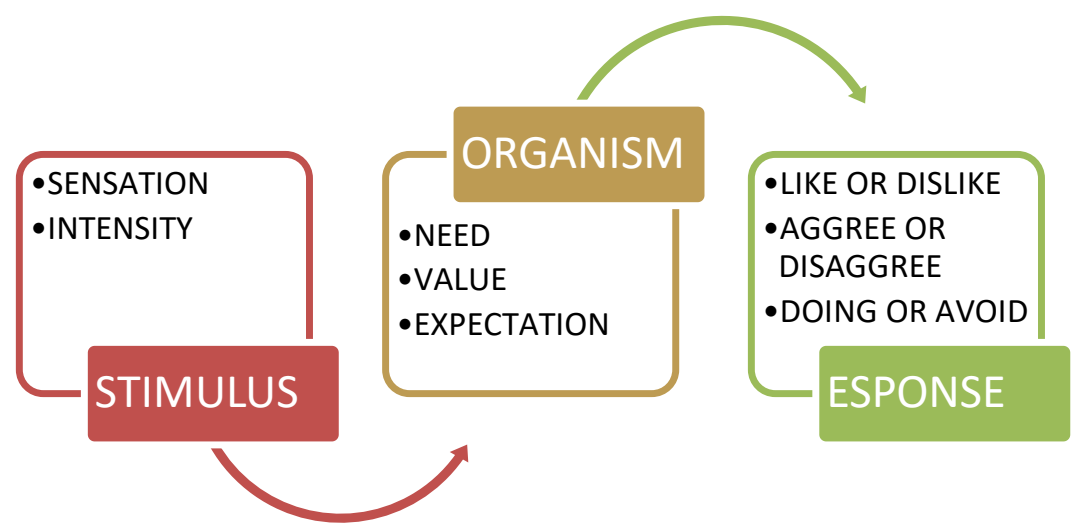

Figure 1. S-O-R's Model of Communications

Source: Kennedy and Dermawan, (2006:125)

The message given to the communicant can be influenced by the sensations produced by them and if the strength of the sensation that is owned and the magnitude of the attraction of the stimulus received it will directly affect the mind of the communicant through the five senses. The mind will select from the stimulus received so that it will produce needs, expectations and values. From these activities will produce a response that will bring changes to positive attitudes or negative attitudes.

Implementation of strategy communications could be used of basic communication's element, like who says what, to whom through what channels, and what effects. Before the company do implementation of communications strategy, this company should prepare internal capabilities to support communication strategies, like choose and assign a communicator, assign of targets and analyzing audience needs, technique of composing messages, and choose the channel (Cangara, 2017:133-139).

Implementation of strategy communication is choose and assign communicator. There are three conditions that must be possessed by the communicator (Cangara, 2017: 133), such as:

a. Credibility

Credibility is the ability of a communicator to interact, so that the public receives messages. A person can be said credible, if the person has communication skills, extensive knowledge about the material, honest and friendly attitude, able to adapt to the social cultural system of society (Berlo in Cangara, 2017: 134).

b. Attractive

Anderson in Cangara (2017: 135) a communicator has an attraction if he has an attractive physical appearance, it is easier to arouse opinions and attitudes.

c. Power 
The ability of a communicator in controlling his personality in conveying messages, namely not easily emotional and smiling (Cangara, 2017: 135).

\section{Public Service}

Public service are all forms of services, in the form of public goods and public services whichin principle are the responsibility and carried out by government agencies at the central, regional, and in the environment of StateOwned Enterprises or Regional-Owned Enterprises, in an effort to needs of the community and in the context of implementing the provisions of the legislation (Ratminto and Winarsih on hardyansyah, 2015:23).

Drajat's research article (2015) with the title Public Services in the Communication Sector, mentions that there are several factors of public service, such as:

a. Optimize public relations institutions

b. Create equity of information

c. The public is given the ease in getting information

d. The creation of a stable political condition and the existence of a similar pattern of government with the management of communication

\section{Public Speaking}

The communicator's ability to convey the message must pay attention to the way of communication. Effective communication in the implementation of public speaking can be identified through five laws of effective communication. In the Cahyono article (2012) mentions five effective communication laws as follows:

a. Respect

The practice of communication in public speaking, empathy is a person's ability to hear what we say. A communicator so that his message is received by others, then the communicator applies an attitude of respect to the communicant. Therefore, there is harmony between the communicator and the communicant to respect each other in listening to the message conveyed.

b. Empathy

The ability of communicators in the practice of public speaking is a way to put yourself in the situations and conditions of others. The purpose of empathy is to get the same feeling connection between the sender and receiver of the message.

c. Audible

The ability of a communicator in public speaking is a message conveyed to others must be heard. This means that a message can be conveyed to others if there is media that supports it. Supporting media in delivering messages is mic, speaker,

d. Clarity

The ability of communicators in the practice of public speaking is a message clear so that the public does not cause multiple interpretations. Communication requires clarity to gain public trust 
e. Humble

Humble is a ability to serve, respect, be willing to listen and accept others' suggestions, not look down on others, accept mistakes.

\section{METHODOLOGY}

This research uses a qualitative approach. The number of informants in this study was 27 people, that all employees of PT TASPEN Branch Mataram. Data collection methods by:

1. Focus group discussion

FGD is one technique in collecting qualitative data; where a group of people discuss with the direction of a facilitator or moderator on a topic (Paramita, 2013: 118). The FGD conducted in this study created a small group, then gave instructions to disseminate information related to product knowledge to each group member.

2. Observasi non partisipan

Non-participant observation is an observation not entirely as a participant, but an observation function (Moleong, 2006: 177). In this study, researchers observed the verbal and nonverbal behavior of PT. Taspen Mataram Branch. Verbal observations that are observed are every message spoken by employees of PT. Taspen Branch Mataram in communication practices (opening, content, closing). Nonverbal observations observed were facial expressions, use of hands, sit of position.

3. Documentation

Documentation of this research is picture of the activity in focus group discussion

4. Post-test

Post test is the final evaluation when the material taught on that day has been given in which a teacher gives a post test with the intention whether the student has understood about the material just given that day (Lenterakecil, 2016). Post test in this study, describes the results of the ability of employees of PT. Taspen Branch Mataram in the practice of communication with customers.

\section{RESULTS AND DISCUSSION}

The results of this study are PT. The Taspen Branch Mataram has new products, namely Taspen Dwiguna Sejahtera, Taspen Scholarship Protection and Taspen Save. The benefits of Taspen Scholarship Protection are (1). Getting death compensation $100 \%$ of the sum insured and the coverage becomes free of premiums, (2). Stages of scholarships in stages and regularly along with pocket money, (3). If the policyholder cancels the policy, then the cash value will be paid. The benefits of Taspen Dwiguna Sejahtera are (1). If the customer dies naturally, they will get $100 \%$ UP plus bonus, if they die due to an accident, they will get 200\% UP plus bonus, (2). If the contract expires, then get a premium return plus a bonus, (3). If the policyholder cancels the policy, he / she will receive the formed cash value. The benefits of Taspen Save are (1). The customer 
will get the final benefit of the contract as much as the accumulated premiums and their development, (2). If the customer stops membership due to something else, the customer will get a cash value benefit, (3). If the customer dies due to illness or accident before the age of retirement, the customer's heir will receive death insurance equal to the sum insured and the cash value at the time the participant dies. Death due to an accident will get 2 times the sum insured.

Business competition in the insurance world, makes PT. Taspen Mataram branch made a new breakthrough. The breakthrough is to train all employees to be able to explain the company's products to customers with various characters. This study tried to explore the ability of employees of PT. Taspen Mataram branch through focus group discussions, communication practices with different customers based on character. Customer characters are quiet, arrogant, and picky, and talkative.

Communication practices are carried out to determine the ability of each employee to understand product knowledge, so that employees can overcome each different type of customer. However, before conducting a simulation of communication practices, there are activities that need to be carried out by all employees of PT. Taspen Branch Mataram is a focus group discussion. Focus group discussion activities can be seen through the following pictures:

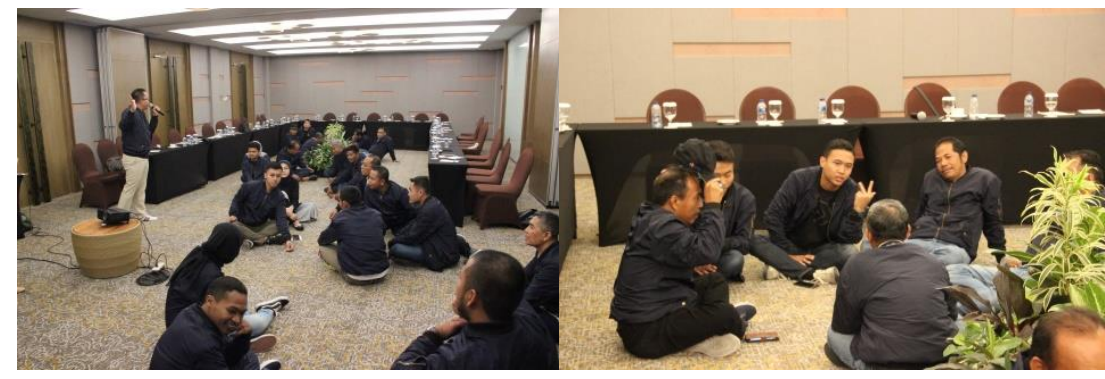

Image 1. Focus Group Discussion of PT. Taspen Branch Mataram

In the above image, the researchers directed all employees of PT. Taspen Brach Mataram forms four small groups. Researchers direct these small groups to learn new product in the company to each member and how the group deals with customers with several types. Group discussions take place within five minutes to teach member about product knowledge. At the end of the discussion, researchers took samples from each group to practice how to provide product information and how to deal with different types of customers. The purpose of this focus group discussion is to train each participant to care about the company by teaching each member product knowledge. Through this activity the result is that each participant knows the importance of product knowledge when dealing with customers outside office hours.. 


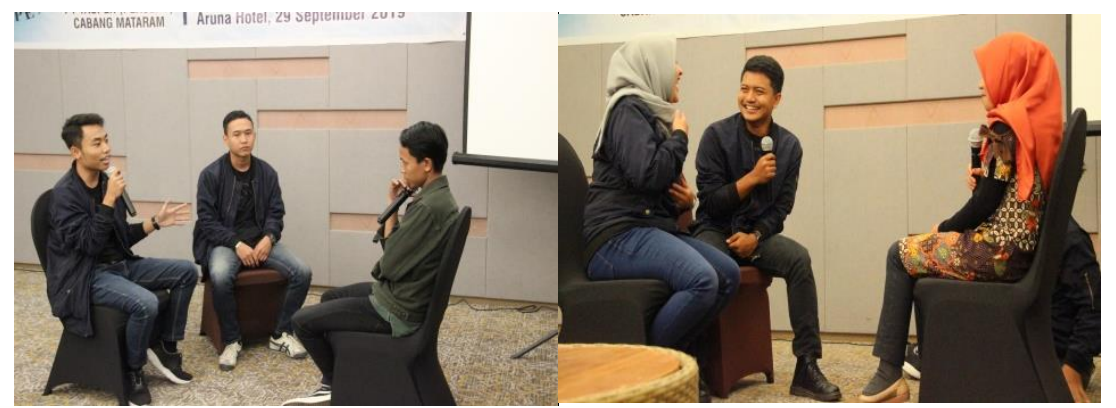

Image 2. Employee of PT. Taspen Branch Mataram are doing practice communications skill with selector and quite Types

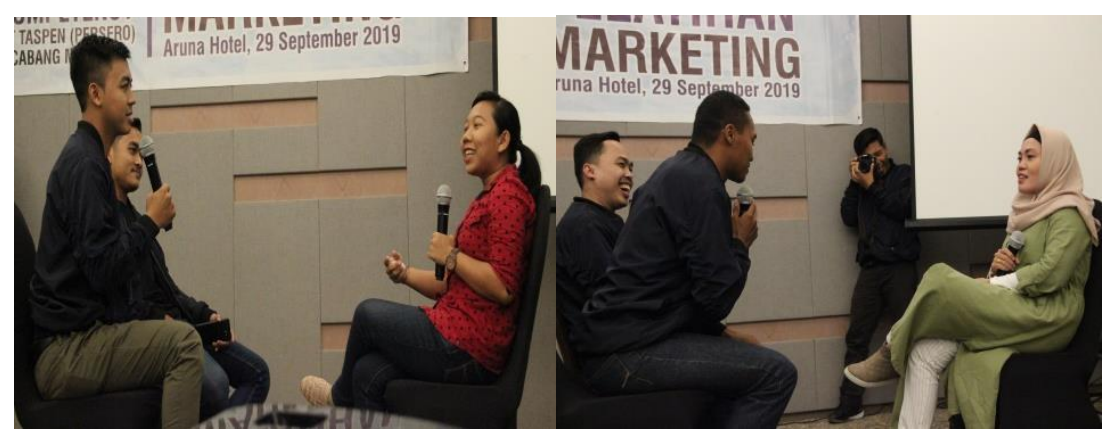

Image 3. Employee of PT. Taspen Branch Mataram are doing practice communications skill with Arrogant and Talkative Types.

Based on the pictures, it can explain that the employees of PT. Taspen Mataram Branch practices communication strategies in approaching customers with various types. The challenge of this activity is the ability of communication, so that customers listen to every message delivered. The result of this communication practice is that each group shows a communication strategy in dealing with customers.

In the picture above, groups dealing with the type of selector, they carry out a strategy by digging up information that is the customer's needs. When this group knows the customer's needs, the next step is to explain the product that matches the customer's needs..

In customers with the silent type, this group becomes challenged to dig up information. they does get information by asking questions about the product. If the customer does not understand the product, the next step is to provide information about the product.

In customers with arrogant type, this group at the beginning of the meeting can control emotions. But when customers start to increase her emotions because the information provided is unclear, this group starts to get emotional, so the 
communication strategy in approaching the customer fails because the customer does not want to take part in the insurance company.

In the last picture, this group is dealing with a talkative customer. This group when dealing with the type of talkative, the strategy is listening every information submitted by the customer. this group records the information submitted. Then the next step, this group provides questions related to customer problems. when the team found out about the problem, the action was taken to give suggestions Taspen's product that could answer customer problems.

The results of this study, researchers also sought information about communication skills not only with hands-on practice, but also with written tests. The test conducted by this researcher aims to get an overview of the practice of communication strategies in providing services to the public. The researcher uses the Google form application, where the researcher has prepared ten multiple choice questions, then all participants answer the question. Post test results can be seen based on the table below:

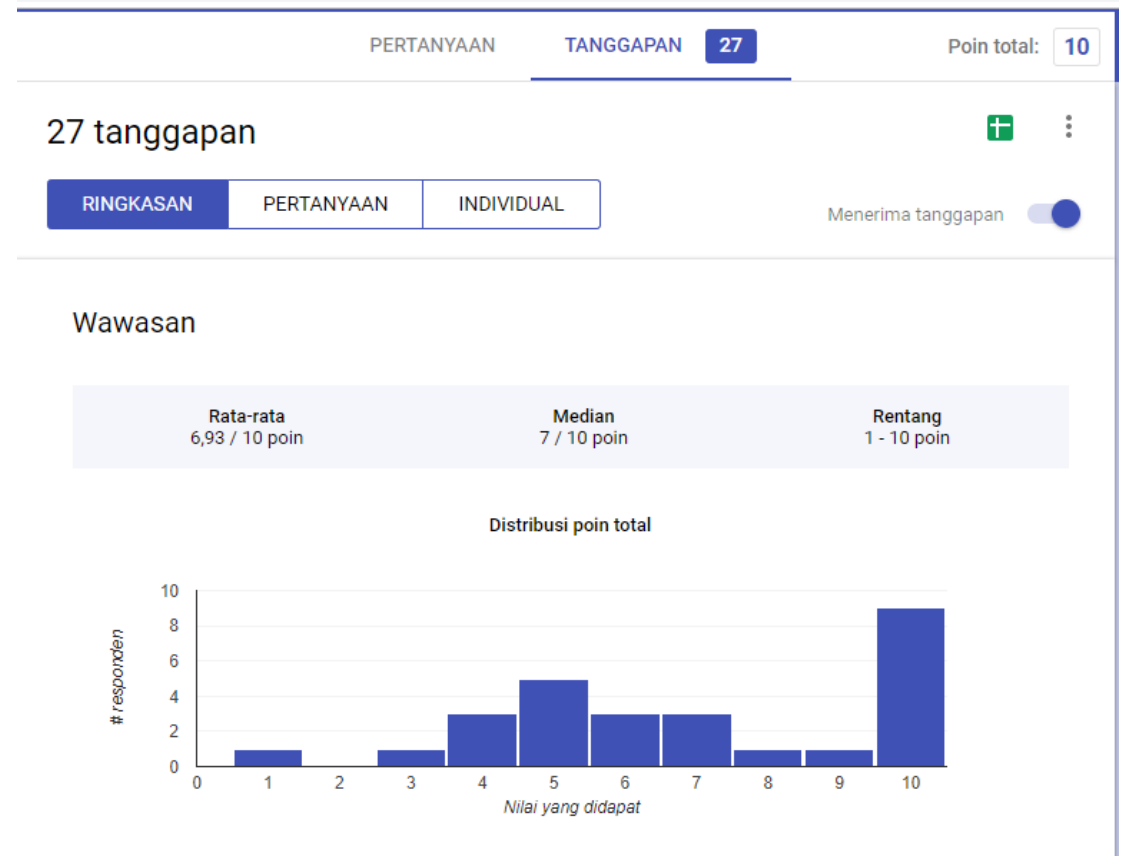

Image 4. Table of Post-Test Result Communication Competency of The Employee PT. Taspen Branch Mataram.

Based on the results of the Post-Test with 27 respondents, there are achievements obtained by employees of PT. Taspen Mataram Branch after participating in competency training activities. The results showed there were nine people with a score of 10 (scale 1-10), five people with a score of 5 , three people 
with a score of 6 , three people with a score of 7 , and each person with a score of $1,3,8,9$.

The Researcher analyzes the communication strategy carried out by the employees of PT. Taspen Branch Mataram based on the S-O-R communication model, that the employees of PT. Taspen Branch Mataram is providing stimulation in the form of communication by giving questions as "inducement" to find out customer needs. The employees deliver product knowledge, the employees giving some solutions if the customers still confuse, the employee giving a joke as a warm impression for customers. Based on the action taken by the employee, this is an act of providing a stimulus to get information from the customer. The customers as an organism needs some information about the products. The employee of PT Taspen Branch Mataram answers customer needs by explaining the product. The response of customers is understanding received by employees of PT. Taspen Mataram Branch.

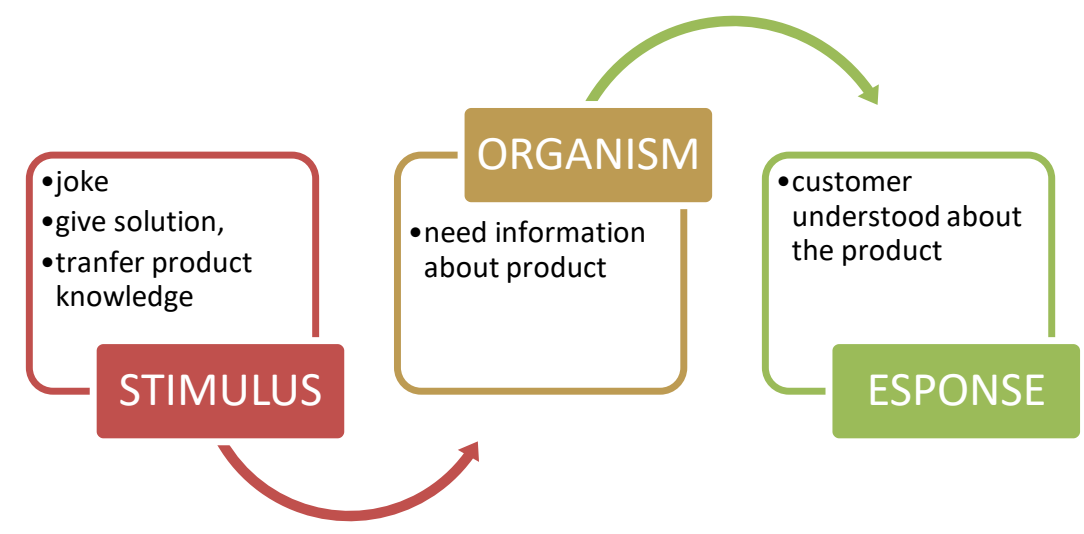

Figure 2. Practice of Effective Communications The Employee Of PT. Taspen Branch Mataram for Customers.

The researcher analyzes of communications strategy by the employee of PT. Taspen Branch Mataram when practice communications is to get the customer's attention. The Strategy of communications has taken by employees of PT. Taspen Branch Mataram from an internal company, which is the company optimizes personal strength. Personal strength in product knowledge, personal strength in explaining the product, personal strength in getting opportunities from customers, personal strength in getting customer's attention. The advantage of implementing the SOR's theory is there is an impact caused by the employees of PT. Taspen Branch Mataram in explaining product knowledge to customers. The impact is the customer understands the product described by the employees of PT. Taspen Branch Mataram.

The researcher analyzes the personal strengths of the employees of PT. Taspen Branch Mataram is the credibility of the employees. The credibility in Cangara's theory is the ability to send a message. This message is product material. The ability possessed by employees is the way for delivered material, 
ranging from product introduction, analyzing customer's need, and the employees giving advice to customers. The employee of PT. Taspen Branch Mataram explains product knowledge clearly. The employees explained about the products in the company, starting from the definition of Taspen Dwiguna Sejahtera products, Taspen Scholarship Protection, and Taspen Save. The employees explain the uses of each product. After explaining about the product, PT. Taspen Branch Mataram, trying to found customer's information to analyze their needs, so that the employees of PT. Taspen Branch Mataram can help customers to suit the product. The activity of sending the message is a form of public service, to give information to the public about insurance's products in PT. Taspen Branch Mataram. The employees of PT. Taspen Branch Mataram tries to analyze customer needs by giving questions related to insurance products. This shows that the delivery of information on insurance products can give customers an idea of the benefits of each product.

The strength of the communication strategy by utilizing the credibility of the employees of PT. Taspen Branch Mataram is the credibility that is owned by all employees, from the leader to the employees become the company's strength in paying attention to the quality of employee performance. The weakness of the communication strategy by utilizing the credibility of the employees of PT. Taspen Branch Mataram is a big challenge for companies to train office boy, security in understanding insurance products.

In addition to the credibility of the employees of PT.Taspen Branch Mataram, an internal communication strategy is an attraction. According to Cangara's theory, the attraction come from the physical of employees. Physical performance displayed by the employees of PT. Taspen Branch Mataram are young men and women. In the results of the study showed that the physical appearance of conducting communication practices were young employees. The researcher analyze, physical appearance is not only in the body, but also nonverbal appearance when interacting with customers. based on the observations of researchers when observing communication practices with customers, researchers saw the employees of PT. Taspen Branch Mataram gives a smile, the way they sit politely, eye contact that is focused on the customer, how to move their hands as reinforcing verbal language. These displays are actions to provide a warm atmosphere in interacting with customers.

According to Cangara, power is the control of one's emotions in conveying messages. Researcher analyze of the four groups that came forward, three groups were able to control emotions when explaining and answering questions from customers. there is one group that has less emotional control, which is facing the arrogant type. The group delivered a message of refusal to the customer who show the arrogance. Researcher analyze the actions taken by the group, that the importance of controlling emotions in dealing with customers. While the three groups showed a positive attitude to the customer, which is still giving a smile and patience to face the customer.

The strenght of attractive implementation is that customers do not feel bored with the appearance of the employees of PT. Taspen Branch Mataram is fresh, full 
of youthful spirit, and gives a warm impression to the customer. the weaknesses of PT. Taspen Branch Mataram is needs to increase ca[ability in nonverbal communication.

PT. Taspen Branch Mataram using personal strength to implementation of communications strategy. The researcher is analyse, the employee needs the public speaking skill that can impact on customers. The employee could explain the product clearly. In this case, the researcher could analyze the effective law of communications as follow:

a. Respect

Respect is the ability to hear the employees of PT. Taspen Branch Mataram. Researcher analyze of employees as good listeners. this is demonstrated to analyze the ability of employees of PT. Taspen Branch mataram as customer's needs. the results of the analysis of researchers, the advantages of how to deliver messages to customers, able to deliver messages in sequence. It means, the employees of PT. Taspen Branch Mataram introduced themselves, then, explained the purpose and objectives, delivered material about insurance, question and answer session about insurance, analysis of customer needs, employees gave advice to customers. The ability of employee is eye contact between employee and customer, give a smile, a little joke, or not go out on topic. But the weakness faced by the employees of PT. Taspen Branch Mataram is not yet explained foreign terms that are not understood by the customer.

b. Emphaty

Emphaty is the ability to feel the same to the customer. This empathy, the researcher analyzes of the ability to be heard or accepted to the customer. The challenge faced by each group is the way customers receive information submitted by the employees of PT. Taspen Branch Mataram. After the employee listens to what the customer needs, this empathy discovers a similarity in feel, in the form of a link between the information of the insurance product, the advice submitted by the employee, and the needs of the custome. The strenght of this theory is that empathy teach the employees of PT. Taspen Branch Mataram to find common tastes between companies and costomers. While the lack of this theory is the practice of communication by employees of PT. The Taspen Branch Mataram only meets the needs of the company.

c. Audible

Audible is the ability of public speaking so that employee voices can be heard clearly by the customer. it means the clarity of the voice becomes important when the employees of PT. Taspen Branch Mataram conveys information related to insurance products. Researchers analyze the sound capabilities of each team has the power to be accepted by the customer. The results showed all customers responded to each message face to face, so that the voice was easily heard. The strenght of audible theory is that it teach the sound power of the employees of PT. Taspen 
Branch Mataram to be heard by customers. while the weakness of the audible theory is that the employees of PT. Taspen Branch Mataram will be weak if it does not have power. The next weakness is that without the support of loudspeakers in large group presentations, it will affect the quality of the sound's power.

d. Clarity

Clarity is a clear message delivered by employees of PT. Taspen Branch Mataram so that it can be accepted by customers. The purpose of clarity is to gain public trust about the insurance product that will be chosen by the customer. The results provide a description, knowledge of insurance products is the initial capital in carrying out communication strategies that can change the mind of the customer, who initially did not know to know about the product. In communication practices, talkative type customers do not understand the message conveyed by employees of PT. Taspen Branch Mataram. The researcher saw, this team conveys messages that were not clear. Unclear because a lot of information that confuses the customer. The strenght of implementing the clarity theory is that the employees of PT. Taspen Branch Mataram can explain product knowledge to customers smoothly and clearly. The weakness of the implementation of this theory is the explanation of product knowledge that is too convoluted, it causes the customer to repeat the question.

e. Humble

Humble is a friendly attitude shown by employees of PT. Taspen Branch Mataram in giving a warm impression to the customer. researchers analyzed based on communication practices carried out by employees of PT. Taspen Branch Mataram, humble attitude is shown through nonverbal messages, like smiles. All groups smile to customers in conveying information. The strenght of implementing this humble theory is that it teach of the employee PT. Taspen Branch Mataram gives a warm impression to customers through a smile. The weakness of the implementation of this theory is that sometimes employees of PT. Taspen Branch Mataram forgot to smile while explaining product knowledge to the customer.

\section{CONCLUSION}

Based on the results of the study with 27 respondents, the researcher concluded that after participating in the FGD activities, the practice of communication competencies, and the post-test communication strategies to employees showed they could face-up to customers with various characters. Strategy of communication in action come from internal corporate. It means, the ppower of personal in corporate could be the strength when they face the customer. Communication services performed by employees show that they have the ability to dig up information that is the customer's need. researchers assess based on the results of the post-test shows that it is necessary to learn more about product 
knowledge, because the employees of PT. The Taspen Mataram branch is able to explain verbally and nonverbally, but requires material learning.

\section{ACKNOWLEDGMENT}

Thanks to The Communications Studies Program of Mataram University in West Nusa Tenggara as sponsor in this research, collegues, PT. Taspen Branch Mataram for opportunity could research in this corporate.

\section{BIODATA}

Yulanda Trisula Sidarta Yohanes, S.I.Kom., M.I.Kom is a lecturer of Communications Science Departement on Mataram University NTB, Indonesia. He has a research interest in public relations, strategy of communications.

\section{REFERENCES}

Cangara, H. Hafied. 2017. Perencanaan dan Strategi Komunikasi. Jakarta: Rajawali Pers.

Moleong, j, Lexy. 2006. Metodologi Penelitian Kualitatif. Bandung: PT. Remaja. Rosdakarya

Cahyono, Ari Dading. 2012. 5 Hukum Komunikasi yang Efektif. https://ardayno.wordpress.com/2012/04/04/5-hukum-komunikasi-yangefektif/ The Articel was accsessed on 25 October 2019 at 08:34 AM

Drajat, Mohamad Subur. 2005. Pelayanan Publik Pada Sektor Komunikasi. https://ejournal.unisba.ac.id/index.php/mediator/article/viewFile/1144/701 The Articel was accsessed on 25 October 2019 at 07:52 AM

Lentera Kecil. 2016. Penilaian dengan Prosedur Pre Test dan Post Test. https://lenterakecil.com/penilaian-pre-test-dan-post-test/ The Articel was accsessed on 25 October 2019 at 08:59 AM

Listyandari, Made Dwi. Et all. Aplikasi Model Stimulus-Organism-Response dalam Keputusan Pembelian. https://simdos.unud.ac.id/uploads/file_penelitian_1_dir/e8077ace1c6ffe87 46d34ea83196fd0a.pdf The articel was accsessd on 25 October 2019 at 07.48 AM

Paramita, Astridyah. Lusi Kristiana. 2013. Teknik Focus Group Discussion dalam Penelitian Kualitatif. https://media.neliti.com/media/publications/20840ID-teknik-focus-group-discussion-dalam-penelitian-kualitatif.pdfThe

Articel was accsessed on 25 October 2019 at 08:56 AM 